\title{
Peran Penyuluh Pertanian Lapang (PPL) dalam Pemberdayaan Petani di Kelompok Tani Sri Widodo Desa Lubang Lor Kecamatan Butuh Kabupaten Purworejo
}

\author{
Istiko Agus Wicaksono ${ }^{1)}$ \\ ${ }^{1}$ Fakultas Pertanian Universitas Muhammadiyah Purworejo. \\ Jl. KHA. Dahlan 3a Purworejo \\ email : istikowicaksono@gmail.com
}

Diterima 20 Maret 2020; layak diterbitkan Juni 2020

\begin{abstract}
Ringkasan
Penelitian ini bertujuan untuk mengetahui peran penyuluh pertanian lapang dalam pemberdayaan petani di Kelompok Tani Sri Widodo Desa Lubang Lor, Kecamatan Butuh, Kabupaten Purworejo. Desain penelitian dilakukan menggunakan metode kualitatif dan data dianalisis secara deskriptif. Responden dalam penelitian ini berjumlah 40 orang petani. Hasil penelitian menunjukkan peran penyuluh pertanian lapang yang meliputi peran sebagai pembimbing petani memiliki kategori sangat berperan $(87,5 \%)$, peran sebagai organisator dan dinamisator memiliki kategori sangat berperan $(87,5 \%)$, peran sebagai teknisi lapangan memiliki kategori sangat berperan $(100 \%)$, dan peran sebagai penghubung dengan peneliti memiliki kategori tidak berperan $(72,5 \%)$. Peran penyuluh pertanian lapang sebagai pembimbing petani, organisator dan dinamisator, dan teknisi lapangan memiliki kategori sangat berperan berarti kegiatan penyuluh sangat dibutuhkan keberadaannya oleh petani dan dapat mengubah kebiasaan petani dalam melakukan usahataninya kearah yang lebih baik dan maju. Adapun peran penyuluh pertanian lapang sebagai penghubung dengan peneliti memiliki kategori tidak berperan berarti kegiatan penyuluhan yang diberikan tidak memiliki dampak atau hasil terhadap pemberdayaan petani di Kelompok Tani Sri Widodo.Hal tersebut disebabkan karena penyuluh pertanian lapang tidak bekerja sama langsung dengan lembaga penelitian sehingga dalam penyampaian informasi mengenai teknologi-teknologi baru kurang maksimal.
\end{abstract}

Kata Kunci: peran, penyuluh pertanian lapang, pemberdayaan petani, kelompok tani

\section{Abstrak}

This study aims to determine the role of field agriculture instructors in the empowerment of farmers in the Sri Widodo Farmers Group, Lubang Lor Village, Need Subdistrict, Purworejo Regency. The study design was carried out using qualitative methods and data were analyzed descriptively. Respondents in this study were 40 farmers. The results showed the role of field agriculture instructors which included the role as a farmer mentor had a very important category (87.5\%), the role of an organizer and a dynamicator had a very important category (87.5\%), the role of a field technician had a very important category (100\%), and the role as a liaison with researchers has a no role category (72.5\%). The role of field agriculture instructors as farmers' guides, organizers and dynamists, and field technicians have a very important category, meaning that extension workers' activities are very much needed by farmers and can change farmers' habits in conducting their farming towards a better and more advanced way. The role of the field agriculture extension agent as a liaison with researchers has no role category, meaning that the extension activities provided do not have an impact or results on the empowerment of farmers in the Sri Widodani Farmer Group. about new technologies is less than the maximum.

Keywords: role, field agriculture instructor, farmer empowerment, farmer groups 


\section{PENDAHULUAN}

Kegiatan penyuluhan dalam pembangunan pertanian berperan sebagai jembatan yang menghubungkan antara praktik yang dijalankan oleh petani dengan pengetahuan dan teknologi petani yang selalu berkembang menjadi kebutuhan para petani tersebut [1]. Agar petani dapat melakukan praktik-praktik yang mendukung usahatani maka petani memerlukan informasi inovasi dibidang pertanian. Informasi tersebut dapat diperoleh petani antara lain dari Penyuluh Pertanian Lapang (PPL) melalui penyelenggaraan kegiatan penyuluhan pertanian. Salah satu strategi dalam program tersebut adalah memberdayakan petani sebagai anggota kelompok tani. Petani dididik untuk lebih mandiri dengan mengandalkan kekuatan mereka sendiri.

Penyuluhan sebagai proses pemberdayaan masyarakat merupakan proses pemandirian masyarakat. Pemandirian bukanlah menggurui dan juga bukan bersifat karikatif, melainkan mensaratkan tumbuh dan berkembangnya partisipasi atau peran serta cara aktif dari semua pihak yang akan menerima manfaat penyuluhan, terutama masyarakat petani sendiri [2]. Salah satu program pemerintah dalam pemberdayaan petani yaitu melalui kelompok tani. Organisasi penyuluhan memegang peran penting dalam membimbing petani mengorganisasikan diri secara efektif. Penyuluh harus ahli pertanian yang kompeten, disamping bisa berkomunikasi secara efektif dengan petani sehinga dapat mendorong minat belajar mereka dan harus berorientasi pada masalah yang dihadapi oleh petani [2].

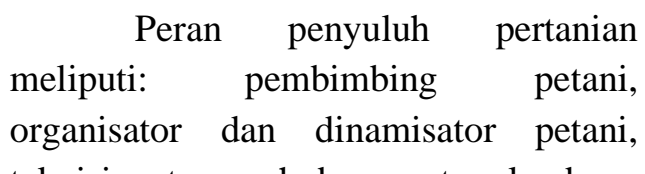
teknisi serta penghubung antara lembaga penelitian dengan petani. Penyuluh pertanian bertugas melakukan pendampingan pertemuan rutin kelompok tani, penyampaian informasi, menumbuh kembangkan kemampuan manajerial dan kewirausahaan. Penyuluhan dilakukan agar dapat memberikan masukan dan membantu petani dalam menyelesaikan masalah yang ada di lapangan khususnya dalam melaksanakan usahatani [3].

Keberadaan kelompok tani di Desa Lubang Lor tidak luput dari peran penyuluh pertanian lapang Dinas Pertanian Pangan, Kelautan dan Perikanan yang berda di Balai Penyuluh Kecamatan Butuh yang mempunyai tujuan meningkatkan pemberdayaan kelembagaan petani di wilayah Kecamatan Butuh. Salah satu faktor yang mempengaruhi pemberdayaan petani anggota kelompok tani adalah terlaksananya peran penyuluh pertanian lapang dengan baik. Namun dalam pemberdayaan petani anggota kelompok tani khususnya di Desa Lubang Lor tidak selalu berjalan dengan baik, masih terdapat beberapa hambatan yang dihadapi. Hambatan tersebut baik dari segi kegiatan kelompok tani maupun dari penyuluh pertanian lapang dan kebijakan pemerintah yang belum sepenuhnya mendukung pemberdayaan petani anggota kelompok tani. Untuk itu diperlukan kajian yang mendalam mengenai peran penyuluh pertanian 
lapang dalam pemberdayaan petani di Kelompok Tani Sri Widodo Desa Lubang Lor Kecamatan Butuh Kabupaten Purworejo.

Penelitian ini bertujuan untuk mengetahui peran penyuluh pertanian lapang dalam pemberdayaan petani di Kelompok Tani Sri Widodo.

\section{METODE PENELITIAN}

Metode dasar yang digunakan dalam penelitian ini adalah metode deskriptif. Metode deskriptif dapat diartikan sebagai prosedur pemecahan masalah yang diselidiki dengan menggambarkan atau melukiskan keadaan obyek penelitian berdasarkan fakta-fakta yang tampak atau sebagaimana adanya. Penelitian deskriptif bertujuan untuk mendeskripsikan apa yang saat ini berlaku.

Untuk menginterpretasikan data menggunakan analisis deskriptif. Penelitian deskriptif bertujuan untuk memberikan gambaran (deskripsi) mengenai suatu data agar data yang tersaji menjadi mudah dipahami dan informatif bagi orang yang membacanya. Penentukan sampel pada penelitian ini, sampel diambil dari anggota Kelompok Tani Sri Widodo. Sampel petani diambil dengan menggunakan metode proportional random sampling [4]. Jumlah responden petani adalah 40 responden.

Teknik pengumpulan data yang digunakan dalam penelitian ini adalah :

1. Observasi, yaitu teknik pengumpulan data dengan cara mengadakan pengamatan secara langsung terhadap petani sampel.

2. Wawancara, yaitu teknik pengumpulan data yang dilakukan dengan mengadakan tanya jawab langsung dengan petani sampel.

3. Pencatatan, yaitu teknik pengumpulan data yang dilaksanakan dengan cara mencacat semua data yang telah ada dan berkaitan dengan tujuan.

4. Studi kepustakaan, yaitu teknik pengumpulan data untuk memperoleh data sekunder yang berkaitan dengan tujuan penelitian.

Jumlah pertanyaan sebanyak 4 item maka diketahui skor maksimumnya yaitu 60 dan skor minimumnya yaitu 20 . Jumlah kategori ditentukan sebanyak tiga kelas yaitu Sangat Berperan, Berperan, dan Tidak Berperan, Indikator dan Skor Peran Penyuluh Pertanian Lapang disajikan Tabel 1.

Hasil perhitungan interval kelas tersebut digunakan untuk menentukan kategori Peran Penyuluh Pertanian Lapang dalam pemberdayaan petani di Kelompok Tani Sri Widodo disajikan pada Tabel 2.

Tabel 1. Indikator dan Skor Peran Penyuluh Pertanian Lapang

\begin{tabular}{llcc}
\hline No. & \multicolumn{1}{c}{ Indikator } & $\begin{array}{c}\text { Skor } \\
\text { Minimum }\end{array}$ & $\begin{array}{c}\text { Skor } \\
\text { Maksimum }\end{array}$ \\
\hline 1 & Penyuluh berperan sebagai pembimbing petani & 5 & 15 \\
2 & Penyuluh berperan sebagai organisator dan motivator & 5 & 15 \\
3 & Penyuluh berperan sebagai teknisi lapangan & 5 & 15 \\
4 & $\begin{array}{l}\text { Penyuluh berperan sebagai penghubung antara } \\
\text { lembaga penelitian dengan petani }\end{array}$ & 5 & 15 \\
\hline \multicolumn{2}{c}{ Jumlah } & 20 & 60 \\
\hline
\end{tabular}


Tabel 2. Kategori Peran PPL dalam Pemberdayaan Petani di Kelompok Tani Sri Widodo

\begin{tabular}{ccc}
\hline No. & Interval Nilai & Kategori Peran PPL dalam Pemberdayaan Petani di Kelompok \\
& Tani Swi Widodo \\
\hline 1. & $20,00-33,33$ & Tidak Berperan \\
2. & $33,34-46,67$ & Berperan \\
3. & $46,68-60,01$ & Sangat Berperan \\
\hline
\end{tabular}

\section{HASIL DAN PEMBAHASAN}

a) Data Petani Sampel Berdasarkan Luas Lahan

Lahan merupakan sarana produksi bagiusaha tani, termasuk salah satu faktor produksidan pabrik hasil pertanian. Lahan adalahsumberdaya alam fisik yang mempunyaiperanan sangat penting bagi petani [5]. Data Petani Sampel Berdasarkan Luas Lahan dalam penelitian ini disajikan pada Tabel 3. Menurut [6], luas lahan petani diglongkan menjadi 3 kategori yaitu petani berlahan luas jika luas lahannya > $2 \mathrm{Ha}$, petani berlahan sedang jika memiliki lahan antara 0,5 - $2 \mathrm{Ha}$, dan petani berlahan sempit jika luas lahannya $<0,5 \mathrm{Ha}$. Berdasarkan hasil penelitian menunjukkan bahwa sebagian besar petani berlahan sedang yakni berjumlah 31 orang $(77,5 \%)$. Hasil ini berbeda dengan [7] bahwa sebagian besar luas lahan Kecamatan Dramaga Kab. Bogor Jawa Barat katagori sempit. Kecamatan Butuh Kabupaten Purworejo merupakan kecamatan dengan area sebagian besar adalah pertanian sehingga petani mempunyai lahan dengan luasan lahan katagori sedang.

\section{a) Sebaran Petani Sampel Berdasarkan Jumlah Anggota Keluarga}

Sebaran Petani Sampel Berdasarkan Jumlah Anggota Keluarga petani di kelompok Tani Sri Widodo Desa Lubang Lor Kecamatan Butuh Kabupaten Purworejo disajikan pada Tabel 4.

Tabel 3. Data Petani Sampel Berdasarkan Luas Lahan

\begin{tabular}{ccccc}
\hline No. & Kategori & Luas Lahan (Ha) & Jumlah (Orang) & Persentase (\%) \\
\hline 1. & Luas & $>2$ & 0 & 0 \\
2. & Sedang & $0,5-2$ & 31 & 77,5 \\
3. & Sempit & $<0,5$ & 9 & 22,5 \\
\hline \multicolumn{2}{r}{ Jumlah } & & 40 & 100,0 \\
\hline
\end{tabular}

Sumber : Analisis Data Primer, 2019.

Tabel 4. Data Petani Sampel Berdasarkan Jumlah Anggota Keluarga

\begin{tabular}{cccc}
\hline No. & Jumlah Anggota Keluarga (Orang) & Jumlah Petani Sampel (Orang) & Persentase (\%) \\
\hline 1. & $1-3$ & 22 & 55 \\
2. & $4-6$ & 18 & 45 \\
\hline & Jumlah & 40 & 100 \\
\hline
\end{tabular}

Sumber : Analisis Data Primer, 2019. 
Tabel 4 menunjukkan jumlah anggota keluarga petani sampel paling banyak mempunyai anggota keluarga 13 orang yaitu sejumlah 22 orang responden atau $55 \%$ dan petani sampel yang mempunyai 4-6 anggota keluarga sebanyak 18 orang responden atau $45 \%$. Hasil ini sama seperti yang dilaporkan oleh [8] bahwa sebagian besar jumlah anggota keluarga adalah 1-3 orang. Jumlah anggota keluarga dalam kaitannya dengan usahatani yaitu

\section{b) Sekolah Lapangan} Pengelolaan Tanaman Terpadu (SLPTT)

Kegiatan SLPTT merupakan salah satu program yang dilaksanakan oleh penyuluh di Desa Lubang Lor Kecamatan Butuh. Kegiatan ini melibatkan seluruh anggota Kelompok Tani Sri Widodo. Adapun tujuan kegiatan ini untuk meningkatkan pengetahuan, keterampilan dan sikap petani sehingga adopsi teknologi berjalan lebih cepat dan berkelanjutan, produktivitas padi sawah dapat meningkat. Selain itu, juga untuk meningkatkan kemandirian Kelompok Tani Sri Widodo. Sekolah Lapang Pengelolaan Tanaman Terpadu (SLPTT) merupakan salah satu komponen dalam program Peningkatan Produksi Beras Nasional yang dilaksanakan Kementerian Pertanian pada tahun 2009-2014. Dengan dukungan anggaran yang besar, pelaksanaan SL-PTT diharapkan dapat berdampak nyata pada peningkatan produksi pangan [10].

c) Sekolah Lapangan Pengelolaan Hama Terpadu (SLPHT)

SLPHT merupakan proses pelembagaan atau adopsi inovasi sebagai tenaga kerja dalam keluarga yang dapat membantu melakukan usahatani. Jumlah anggota keluarga dapat mempengaruhi produksi pertanian. Anggota keluarga petani responden berperan aktif dalam mendorong pelaksanaan usahatani lahan Pekarangan. Suami berperan dalam kegiatan pengelolaan tanah dan penanam bibit sedangkan anak dan istri berperan dalam pemeliharan tanaman serta kegiatan dalam pemanenan[9].

sistem usahatani Padi Sawah dalam upaya optimalisasi pemanfaatan lahan sawah irigasi [11]. Kegiatan ini melibatkan seluruh anggota Kelompok Tani Sri Widodo. Anggota kelompok tani diberikan pengetahuan dan keterampilan yang didasarkan pada pemahaman dan keterampilan menerapkan prinsip-prinsip pengelolaan hama terpadu dalam budidaya tanaman padi, sehingga petani dapat mengetahui bagaimana cara untuk pencegahan atau mengatasi serangan hama pada usahataninya. Kegiatan SLPHT bertujuan untuk membuat petani menjadi petani yang professional, aktif, kreatif dan produktif dalam mengembangkan pengelolaan hama terpadu. Perilaku para petani mengembangkan sistem PHT adalah hasil dari proses belajar dan bekerja yang sistematik, berkelanjutan dan terprogram dalam suatu sistem interaksi antara petani sebagai subjek, dengan aparatur penyuluhan pertanian sebagai fasilitator atau pemandunya.

\section{d) Peran Penyuluh Pertanian Lapang Dalam Pemberdayaan Petani}

[12] seorang penyuluh mempunyai peran sebagai pembimbing, organisator dan dinamisator, pelatih 
teknis, dan penghubung petani dengan lembaga penelitian bidang pertanian. Peran tersebut merupakan upaya penyuluh dalam memberdayakan petani untuk mengembangkan, memandirikan, mengswadayakan dan meningkatkan posisi tawar petani terhadap usaha taninya. Terkait dengan pemberdayaan petani padi, peran penyuluh adalah mengubah kebiasaan petani dalam melakukan usahataninya kearah yang lebih baik dan maju. Sebaran pendapat responden terhadap peran penyuluh pertanian lapang pada Tabel 5. Kategori sangat berperan berarti kegiatan penyuluhan sangat dibutuhkan keberadaannya oleh petani dan dapat mengubah kebiasaan petani dalam melakukan usahataninya kearah yang lebih baik dan maju.

Tabel 5. Sebaran Pendapat Responden Terhadap Peran Penyuluh Pertanian Lapang

\begin{tabular}{cclrr}
\hline No. & Peran Penyuluh & \multicolumn{1}{c}{ Kategori } & Jumlah (Orang) & Persentase $(\%)$ \\
\hline 1. & Pembimbing Petani & Tidak Berperan & 0 & 0 \\
& & Berperan & 5 & 12,5 \\
& & Sangat Berperan & 35 & 87,5 \\
2. & Organisator dan & Tidak Berperan & 0 & 0 \\
& Motivator & Berperan & 5 & 12,5 \\
& & Sangat Berperan & 35 & 87,5 \\
3. & Pelatih Teknis & Tidak Berperan & 0 & 0 \\
& & Berperan & 0 & 0 \\
4 & & Sangat Berperan & 40 & 100 \\
& Penghubung dengan & Tidak Berperan & 29 & 72,5 \\
& Peneliti & Berperan & 11 & 27,5 \\
& & Sangat Berperan & 0 & 0 \\
\hline
\end{tabular}

Sumber : Analisis Data Primer, 2019.

\section{a) Pembimbing Petani}

Berdasarkan data pada Tabel 5 dapat dilihat bahwa peran penyuluh pertanian lapang dinilai sangat berperan ketika penyuluh sangat berperan sebagai pembimbing petani dengan skor $87,5 \%$. Sebagai seorang pembimbing petani, penyuluh pertanian lapang berperan sebagai pembimbing sekaligus guru bagi petani dalam bidang pertanian. Penyuluh memiliki gagasan yang tinggi mengenai cara mengatasi hambatan dan pembangunan pertanian yang berasal dari petani itu sendiri. Seorang penyuluh harus mengenal baik sistem usahatani dan bersimpati terhadap kehidupan petani serta mampu membantu dalam pengambilan keputusan yang dilakukan oleh petani sehingga mampu memberikan masukan yang baik. Penyuluh harus mampu membimbing petani mengenai tata cara atau metode budidaya tanaman, membantu petani dalam menempatkan dan menggunakan atau mengoperasikan sarana prasarana pertanian sesuai kegunaannya. Penyuluh harus mampu memberikan solusi sumber dana kredit yang dapat digunakan oleh petani untuk mengembangkan usahataninya dan mampu memberikan pengetahuan mengenai perkembangan informasi yang berada di instansi-instansi terkait.

\section{b) Organisator dan Motivator}

Berdasarkan data pada Tabel 5 dapat dilihat bahwa peran penyuluh pertanian lapang sebagai Organisator dan Motivator dinilai sangat berperan 
dengan skor $87,5 \%$ Peran penyuluh sebagai organisator dan dinamisator terkait dengan pembentukan dan pengembangan kelompok tani. Penyelenggaraan yang dilakukan oleh penyuluh pertanian lapang tidak memungkinkan untuk melakukan kunjungan ke masing-masing petani sehingga petani diajak untuk membentuk suatu kelompok-kelompok tani untuk mempermudah penyuluh melakukan penyuluhan mengenai program-program pertanian. Peran penyuluh sebagai motivator membantu petani dalam mendapatkan informasi tentang bagaimana cara mengolah hasil - hasil produksinya, memberikan arahan bagaimana cara mengolah lahan yang baik, cara menggunakan teknologi, cara bagaimana meningkatkan nilai tambah dari hasil produksi, serta memberikan contoh dan memotivasi petani tentang cara bertani yang baik [13].

\section{c) Pelatih Teknis}

Berdasarkan data pada Tabel 5 dapat dilihat bahwa peran penyuluh pertanian lapang dinilai sangat berperan ketika penyuluh berperan sebagai pelatih teknis sangat berperan dengan skor $100 \%$. Hasil ini sama yang dilaporkan oleh [14] bahwa penyuluh berperan penting sebagai pelatih teknis. Peran penyuluh sebagai pelatih teknis berkaitan dengan pengetahuan dan keterampilan teknis. Seorang penyuluh pertanian lapang harus mempunyai pengetahuan yang luas mengenai pertanian dan harus memiliki keterampilan teknis yang baik. Kondisi di lapangan, petani terkadang meminta penyuluh untuk mempraktikkan apa yang telah didemonstrasikan mengenai program-program yang diberikan. Tanpa adanya pengetahuan luas dan keterampilan teknis maka akan sulit bagi penyuluh untuk memberikan pelayanan jasa konsultan yang diminta secara langsung maupun tidak langsung [15].

\section{d) Penghubung dengan Peneliti}

Peran penyuluh sebagai penghubung dengan peneliti dinilai tidak berperan. Hal ini berarti kegiatan penyuluhan yang diberikan tidak ada dampak atau hasil terhadap pemberdayaan petani. Hal tersebut disebabkan karena penyuluh tidak bekerjasama langsung dengan lembaga penelitian pertanian sehingga dalam penyampaian informasi mengenai teknologi-teknologi terbaru kurang maksimal. Peran penyuluh sebagai penghubung dengan lembaga penelitian pertanian berkaitan dengan hasil penelitian pertanian. Penyuluh bertugas menyampaikan hasil temuan lembaga penelitian pertanian kepada petani. Sebaliknya petani menyampaikan hasil pelaksanaan penerapan atas penelitian tersebut kepada lembaga penelitian pertanian melalui penyuluh sebagai umpan balik atas hasil yang diinginkan. Dalam hal ini, seorang penyuluh melaporkan hasil kepada lembaga penelitian sebagai bahan referensi lebih lanjut. nyuluh sebagai penghubung menyampaikan aspirasi petani dan peneliti yaitu senantiasa membawa inovasi baru hasil-hasil penelitian untuk dapat memajukan usaha tani [16].

\section{KESIMPULAN}

Peran penyuluh pertanian lapang dalam pemberdayaan petani dinilai sangat berperan ketika penyuluh berperan sebagai pembimbing petani, organisator dan motivator, dan pelatih teknis. Kategori sangat berperan berarti kegiatan 
penyuluhan sangat dibutuhkan keberadaannya oleh petani dan dapat mengubah kebiasaan petani dalam melakukan usahataninya kearah yang lebih baik dan maju. Sedangkan peran penyuluh sebagai penghubung dengan peneliti dinilai tidak berperan. Hal ini berarti kegiatan penyuluhan yang diberikan tidak ada dampak atau hasil terhadap pemberdayaan petani. Hal tersebut disebabkan karena penyuluh tidak bekerjasama langsung dengan lembaga penelitian pertanian sehingga dalam penyampaian informasi mengenai teknologi-teknologi terbaru kurang maksimal.

Penyuluh pertanian lapang sebaiknya mampu menjembatani petani dengan peneliti dengan cara mengikutsertakan petani pada saat kunjungan ke balai penelitian dengan harapan akan tercipta kerjasama antara petani, penyuluh pertanian lapang, dan peneliti agar pertanian lebih maju.

\section{REFERENSI}

[1] G. Kartasapoetra, "Teknologi Penyuluhan Pertanian." Bumi Aksara, Jakarta, 1994.

[2] T. Mardikanto, Sistem Penyuluhan Pertanian. LPP UNS dan UNS Press. Surakarta, Jawa Tengah. Surakarta, Jawa Tengah: LPP UNS dan UNS Press., 2009.

[3] Suhardiyono, Penyuluhan Pertanian Terjemahan dari Agriculture. Jakarta: Mitra Wacana. Jakarta: Mitra Wacana, 1992.

[4] Sugiyono, Metode Penelitian Kuantitatif dan Kualitatif. Bandung: Alfabeta, 2012.

[5] M. Mandang and D. Tolok, "Karakteristik Petani Berlahan Sempit Di Desa Tolok Kecamatan Tompaso," Agri-Sosioekonomi, vol. 16, no. 1, pp. 105-114, 2020, doi:10.35791/agrsosek. 16.1.2020. 27131.

[6] F. Hernanto, "Ilmu Usahatani." Penebar Swadaya, Jakarta, 2007.

[7] I. Manyamsari, "Agrisep Vol (15) No. 2 , 2014 58," no. 2, pp. 5874, 2014.

[8] H. D. Bancin, Imelda, and N. Kusrini, "Hubungan Karakteristik Dan Kesejahteraan Petani Padi Sawah Tadah Hujan Di Kecamatan Sungai Kaka," Pertanian Universitas Tanjungpura Pontianak, 2019.

[9] Cepriadi and R. Yulida, "Persepsi Petani Terhadap Usahatani Lahan Pekarangan (Studi Kasus Usahatani Lahan Pekarangan Di Kecamatan Kerinci Kabupaten Pelalawan)," Indones. J. Agric., vol. 3, no. 2, pp. 177-194, 2012.

[10] T. Nurasa and H. Supriyadi, "Program Sekolah Lapang Pengelolaan Tanaman Terpadu (Sl-Ptt) Padi: Kinerja Dan Antisipasi Kebijakan Mendukung Swasembada Pangan Berkelanjutan," Anal. Kebijak. Pertan., vol. 10, no. 4, pp. 313329, 2012.

[11] M. A. D. Zakil, Y. Rusman, and M. N. Yusuf, "Dampak Sekolah Lapang Pengendalian Hama Terpadu (Slpht) Terhadap Tingkat Penerapan Teknologi Pengendalian Hama Terpadu (Pht) Pada Usaha Tani Padi Sawah (Oryza Sativa L.)(Studi Kasus Pada Kelompok Tani Raksa Bumi Iii Desa Sindangsari Kecamatan Kawali Kabup," $J$. Ilm. Mhs. AGROINFO GALUH Vol., vol. 1, no. 4, p. 2014, 2014, doi: 10.25157/jimag.v1i1.285.

[12] A. W. dan Van Den Ban and H. S. Hawkins, Penyuluh Pertanian. Kanisius. Jogyakarta., 2012.

[13] D. N. V. D. Marbun, S. Satmoko, and S. Gayatri, "Peran Penyuluh Pertanian dalam Pengembangan 
Jurnal RISET Agribisnis dan Peternakan

Vol. 5, No. 1, Juni 2020, Hal 59 - 67

Peran Penyuluh .....

ISSN 2527-9912

E- ISSN 2614-8145

Kelompok Tani Tanaman

Hortikultura di Kecamatan

Siborongborong, Kabupaten

Tapanuli," J. Ekon. Pertan. dan

Agribisnis, vol. 3, no. 3, pp. 537-

546, 2019, doi:

10.21776/ub.jepa.2019.003.03.9.

[14] I. Widuri, M. Effendi, and Herson, "The Role of Agricultural Extension in the Application of Cultivation Technology of Tomato (Lycopersicun esculentum L .) in Loleng Village Kota Bangun Subdistrict Kutai Kartanegara District," J. Agribisnis. Komun. Pertan, vol. 1, no. April, pp. 25-38, 2018, doi: DOI: http://dx.doi.org/10.35941/akp.1.1 .2018.1701.25-38 Page.

[15] S. B. . Putra, "Peran Penyuluh Pertanian Dalam Pengembangan Kelompok Tani Padi Sawah Di Desa Rambah Baru Kecamatan Rambah Samo Kabupaten Rokan Hulu," Universitas Pasir Pengaraian Rokan Hulu, 2016.

[16] Sundari, A. H. A. Yusra, and Nurliza, "Peran Penyuluh Pertanian Terhadap Peningkatan Produksi Usahatani Di Kabupaten Pontianak," J. Soc. Econ. Agric., vol. 4, no. 1, pp. 26-31, 2015, doi: $10.3969 /$ j.issn.10080813.2015.03.002. 